\title{
FERMT3 wt Allele
}

National Cancer Institute

\section{Source}

National Cancer Institute. FERMT3 wt Allele. NCI Thesaurus. Code C117076.

Human FERMT 3 wild-type allele is located in the vicinity of 11q13.1 and is approximately $17 \mathrm{~kb}$ in length. This allele, which encodes fermitin family homolog 3 protein, is involved in the modulation of cell adhesion. Mutation of the gene is associated with leukocyte adhesion deficiency-3. 